\title{
Composition and leishmanicidal activity of the essential oil of Vernonia polyanthes Less (Asteraceae)
}

\section{Raquel Regina Duarte Moreira, Gilmarcio Zimmermann Martins, Raquel Varandas, Juliana Cogo, Caio Humberto Perego, Giovana Roncoli, Maria do Céu Sousa, Celso Vataru Nakamura, Lígia Salgueiro \& Carlos Cavaleiro}

To cite this article: Raquel Regina Duarte Moreira, Gilmarcio Zimmermann Martins, Raquel Varandas, Juliana Cogo, Caio Humberto Perego, Giovana Roncoli, Maria do Céu Sousa, Celso Vataru Nakamura, Lígia Salgueiro \& Carlos Cavaleiro (2017) Composition and leishmanicidal activity of the essential oil of Vernonia polyanthes Less (Asteraceae), Natural Product Research, 31:24, 2905-2908, DOI: 10.1080/14786419.2017.1299723

To link to this article: https://doi.org/10.1080/14786419.2017.1299723

+ View supplementary material $๘$

Submit your article to this journal $₫$
曲 Published online: 03 Apr 2017. 


\title{
Composition and leishmanicidal activity of the essential oil of Vernonia polyanthes Less (Asteraceae)
}

\author{
Raquel Regina Duarte Moreira ${ }^{\mathrm{a}}$ (D), Gilmarcio Zimmermann Martins ${ }^{\mathrm{b}}$, Raquel \\ Varandas ${ }^{e}$, Juliana Cogoc, Caio Humberto Perego a , Giovana Roncolib ${ }^{b}$, Maria do Céu \\ Sousa ${ }^{\mathrm{e}}$, Celso Vataru Nakamurac, Lígia Salgueiro ${ }^{\mathrm{d}, \mathrm{e}}$ and Carlos Cavaleiro ${ }^{\mathrm{d}, \mathrm{e}}$
}

aFaculdade de Ciências Farmacêuticas, Departamento de Princípios Ativos Naturais e Toxicologia, Universidade

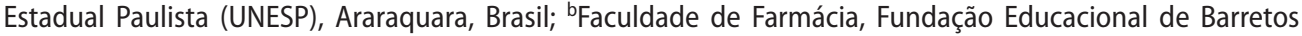
UNIFEB, Barretos, Brasil; 'Faculdade de Farmácia, Universidade Estadual de Maringá, Paraná, Brasil; ${ }^{\text {dCentro }}$ de Neurociências e Biologia Celular, Universidade de Coimbra, Coimbra, Portugal; 'Faculdade de Farmácia, Universidade de Coimbra, Coimbra, Portugal

\section{ABSTRACT}

The composition of the essential oil (EO) from leaves of Vernonia polyanthes and the evaluation of its leishmanicidal potential are reported here for the first time. The oil obtained by hydrodistillation was analysed by combination of GC and GC/MS. Thirty-five compounds were identified, representing $91.8 \%$ of the oil composition. The oil consists primarily of monoterpenes $(37.1 \%)$, sesquiterpenes $(26.3 \%)$ and oxygenated sesquiterpenes $(23.9 \%)$, myrcene $(34.3 \%)$, zerumbone (15.8\%), bicyclogermacrene (8.9\%), a-humulene $(4.8 \%)$ and germacrene $D(4.3 \%)$ being the major constituents. Activity against Leishmania infantum was determined using the tetrazolium dye (MTT) colorimetric method. The oil, as well as zerumbone, one of its major constituents, showed significant leishmanicidal activity, with $\mathrm{IC}_{50}$ values of 19.4 and $9.0 \mu \mathrm{g} / \mathrm{ml}$, respectively. Cytotoxicity in macrophages cells was evaluated using the MTT colorimetric assay. The EO showed the $\mathrm{CC}_{50}<10 \mu \mathrm{g} / \mathrm{ml}$ to macrophages cells.

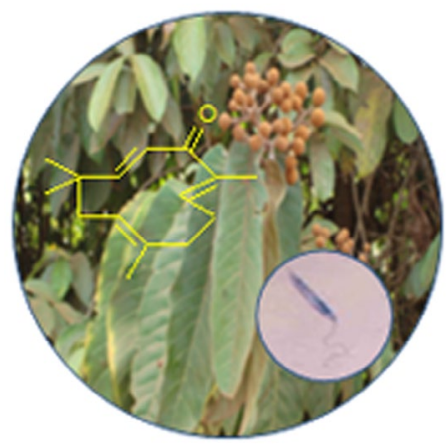

ARTICLE HISTORY

Received 11 October 2016

Accepted 20 February 2017

\section{KEYWORDS}

Vernonia polyanthes; Leishmania infantum; essential oil; zerumbone; leishmanicidal activity 


\section{Introduction}

Leishmania infantum is the causative agent of disseminated visceral leishmaniasis (VL), the most severe form of the disease. It is fatal if left untreated, characterised by irregular bouts of fever, weight loss, enlargement of the spleen, liver and anaemia (WHO 2015). It estimated 300,000 new cases, over 20,000 deaths, annually, and point to 310 million of people at risk of infection (WHO 2015). The current treatment leading to serious adverse effects and poor tolerance and increasing resistance of the parasites contributes for the ineffectiveness of the therapeutic regimens (Croft et al. 2006). For these reasons, the development of novel antileishmanial agents and new therapeutic strategies justifies major consideration. Plants may be alternative sources to look for new agents against leishmaniasis. Recently, several authors have evaluated the leismanicidal activity of natural products. Lima et al. (2016) evaluated the leishmanicidal activity of Calea uniflora Less. Shyaula et al. (2016) showed the antileishmanial activity of the Aconitum spicatum (Bruhl) StapfAnd Sosa et al. (2016) demonstrated that sesquiterpene lactones were active against against Leishmania amazonensis and Leishmania braziliensis. Vernonia polyanthes Less (Asteraceae) popularly known as'assapeixe' is a common plant of the Brazilian 'Cerrado'. In folk medicine, the herbal tea is used as anti-inflammatory, anthelmintic, febrifuge and for treatment of the pneumonia (Lorenzi \& Matos 2008). Among other biological activities of $V$. polyanthes, the antiliesihmanial effects on L. amazonensis (Braga et al. 2007) stand out.

The lack of scientific knowledge on $V$. polyanthes encouraged us to investigate the composition of the essential oil and to evaluate its worth as a potential source of leishmanicidal agents against $L$. infantum.

\section{Results and discussion}

Thirty-five constituents were identified, representing $91.8 \%$ of the total composition. The oil consists predominantly of monoterpene hydrocarbons (37.1\%), sesquiterpene hydrocarbons (26.3\%) and oxygen containing sesquiterpenes (23.9\%). Myrcene (34.3\%), bicyclogermacrene (8.9\%), $\alpha$-humulene (4.8\%), germacrene D (4.3\%) and zerumbone (15.8\%) were found to be the major constituents. The composition of the EO of several species of Vernonia is characterised by high amounts of sesquiterpene hydrocarbons, as (E)-caryophyllene, bicyclogermacrene and $\alpha$-humulene, showed in V. brasiliana, V. remotiflora, $V$. chalybaea and $V$. scorpioides (Maia et al. 2010). Our results are in agreement with these results since the oil of $V$. polyanthes has high levels of sesquiterpenes. However, the oil of this species is distinguished by the high content of zerumbone; sesquiterpenic ketone derived from the humulane nucleus was first recognised in the EO of Zingiber zerumbet (Balakrishnan et al. 1956). The biological evaluations showed strong antitumor activity (Zhang et al. 2012), antimalarial and activity against $L$. donovani (Singh et al. 2014). Our results on the evaluation of the leishmanicidal activity of the EO of $V$. polyanthes and zerumbone are shown in Table 1.

Table 1. Inhibitory concentrations at $50 \%\left(\mathrm{IC}_{50}\right)$ of Vernonia polyanthes essential oil and zerumbone on Leishmania infantum promastigotes.

\begin{tabular}{llcc}
\hline & E.O. of Vernonia & Zerumbone & Miltefosine \\
\hline $\mathrm{IC}_{50}\left(\mu \mathrm{g} \cdot \mathrm{ml}^{-1}\right)$ & $19.4(16.3-23.0)^{\mathrm{a}}$ & $9.0(7.3-10.9)^{\mathrm{a}}$ & $19.0(16.3-26.6)$ \\
\hline
\end{tabular}

aConfidence interval at 95\%. 
Myrcene, the major compound of the oil, was previously reported as not active against $L$. infantum $\left(\mathrm{IC}_{50}=164.0 \mathrm{\mu g} / \mathrm{ml}\right.$ ) (Machado et al. 2012). The EO of $\mathrm{V}$. polyanthes exhibited a significant activity against $L$. infantum promastigote forms, with $I C_{50}$ value of $19.4 \mu \mathrm{g} / \mathrm{ml}$. IC $C_{50}$ value of zerumbone was estimated to be $9.0 \mu \mathrm{g} / \mathrm{ml}(\mathrm{ca} .41 .2 \mu \mathrm{M})$, being plausible to assign the most of the activity of the oil to this compound. This finding is consistent with the results recorded by Singh et al. (2014) that estimated the activity of zerumbone on L. donovani $\left(I C_{50}<1.6\right.$ and $I C_{90}=4.69 \mu \mathrm{g} / \mathrm{ml}$, approx. $7.3 \mu \mathrm{M}$ and $\left.21.5 \mu \mathrm{M}\right)$. Several compounds of this class, such as nerolidol, $\alpha$-bisabolol and polygodial, are associated to antileishmanial effects (Arruda et al. 2005; Morales-Yuste et al. 2010). So, the influence of others sesquiterpenic components present in the EO action of $V$. polyanthes against $L$. infantum cannot be excluded. The activity of the EO might depend of the minor oil components and/or on synergistic effects. Experiments revealed that the essential oil showed the $\mathrm{CC}_{50}<10 \mu \mathrm{g} / \mathrm{ml}$ to macrophages cells.

\section{Conclusions}

As our knowledge, this is the first report on the composition of the EO of $\mathrm{V}$. polyanthes (leaves) and on its leishmanicidal potential as well as of zerumbone, one of its major components. Results encourage further research to elucidate the kinetics and the mechanisms behind the effects of zerumbone on L. infantum amastigote forms.

\section{Conflicts of interest}

The authors declare that they have no conflict of interest.

\section{Funding}

This work was supported by Programa Ciência Sem Fronteiras/CNPq; INCT-if; PADC-FCFAR-UNESPAraraquara-SP-Brasil; and Programa Operacional Ciência e Inovação 2010 (POCI)/FEDER/Fundação para a Ciência e Tecnologia (FCT).

\section{ORCID}

Raquel Regina Duarte Moreira (D) http://orcid.org/0000-0002-6457-7402

\section{References}

Arruda DC, D'Alexandri FL, Katzin AM, Uliana SRB. 2005. Antileishmanial activity of the terpene nerolidol. Antimicrob Agents Chemother. 49:1679-1687.

Balakrishnan RK, Radzan RK, Bhattacharyya SC. 1956. Oil of Zingiber zerumbet Smith. Part 1. Isolation of various constituents and characterization of the inonocyclic ketone zerumbone. Perfum Essent Oil Rec. 47:274-279.

Braga FG, Bouzada MLM, Fabri RL, Matos MO, Moreira FO, Scio E, Coimbra ES. 2007. Antileishmanial and antifungal activity of plants used in traditional medicine in Brazil. J Ethnopharmacol. 111:396-402.

Croft SL, Sundar S, Fairlamb AH. 2006. Drug resistance in leishmaniasis. Clin Microbiol Rev. 19:111-126.

Lima TC, Souza RJ, Santos ADC, Moraes MH, Biondo NE, Barison A, Steindel M, Biavatti MW. 2016. Evaluation of leishmanicidal and trypanocidal activities of phenolic compounds from Calea uniflora Less. Nat Prod Res. 30:551-557. 
Lorenzi HL, Matos FJA. 2008. Plantas Medicinais no Brasil: Nativas e Exóticas. 2nd ed. Nova Odessa: Instituto Plantarum; p. 165-166.

Machado M, Pires P, Dinis AM, Santos-Rosa M, Alves V, Salgueiro L, Cavaleiro C, Sousa MC. 2012. Monoterpenic aldehydes as potential anti-Leishmania agents: activity of Cymbopogon citratos and citral on L. infantum, L. tropica and L. major. Exp Parasitol. 130:223-231.

Maia AIV, Torres MCM, Pessoa ODL, Menezes JESA, Costa SMO, Nogueira VLR, Melo VMM, Souza EB, Cavalcante MGB, Albuquerque MRJR. 2010. Essential oils of leaves of Vernonia remotiflora and Vernonia brasiliana: chemical composition and biological activity. Quím Nova. 33:584-586.

Morales-Yuste M, Morillas-Márquez F, Martín-Sánchez J, Valero-López A, Navarro-Moll MC. 2010. Activity of (-)-a-bisabolol against Leishmania infantum promastigotes. Phytomedicine. 17:279-281.

Shyaula SL, Tamang T, Ghouri N, Adhikari A, Marasini S, Bajracharya GB, Mangala D, Manandhar MD, Choudhary MI. 2016. Antileishmanial diterpenoid alkaloids from Aconitum spicatum (Bruhl) Stapf. Nat Prod Res. 30:2590-2593.

Singh CB, Chanu SB, Lenin KH, Swapana N, Cantrell C, Ross SA. 2014. Chemical composition and biological activity of the essential oil of rhizome of Zingiber zerumbet (L.) Smith. J Pharmacogn Phytochem. 3:130-133.

Sosa AM, Amaya S, Capusiri ES, Gilabert M, Bardón A, Giménez A, Nancy R, Vera NR, Borkosky SA. 2016. Active sesquiterpene lactones against Leishmania amazonensis and Leishmania braziliensis. Nat Prod Res. 30:2611-2615.

WHO (World Health Organization). 2015 Feb. Leishmaniasis fact sheet №375 [Internet]. [cited 2015 Apr 16]. Available from: http://www.who.int/leishmaniasis/en/

Zhang S, Liu Q, Liu Y, Qiao H, Liu Y. 2012. Zerumbone, a Southeast Asian ginger sesquiterpene, induced apoptosis of pancreatic carcinoma cells throughp53 signaling pathway. Evidence-Based Complementary Altern Med. 2012:1-8. 